\title{
Waspada Demam Berdarah: Penyegaran Pengetahuan Antisipasi, Pencegahan dan Tanggap Gejala bagi Warga Dusun Ciren, Triharjo, Pandak, Bantul, DIY \\ Dian Purwita Sari ${ }^{1}$, Fajar Agung Dwi Hartanto ${ }^{2}$ \\ 1,2Prodi Sarjana Farmasi, Sekolah Tinggi Ilmu Kesehatan Notokusumo Yogyakarta e-mail: ${ }^{1}$ sari.dianpur@gmail.com, ${ }^{2}$ fajaragungdh@gmail.com
}

\begin{abstract}
ABSTRAK Indonesia merupakan negara tropis yang memiliki problem penyakit infeksi menular salah satunya adalah Demam Berdarah Dengue (DBD). Nyamuk Aedes aegypti dan Aedes albocpictus yang merupakan vektor penularan DBD dapat berkembang pesat di iklim tropis yang lembab dan hangat serta curah hujan yang tinggi. Angka kejadian DBD di Indonesia masih berfluktuasi naik dan turun tiap tahunnya, menandakan bahwa upaya pencegahan belum konsisten mendorong trend penurunan angka kejadian. Pencegahan pada perilaku masyarakat dalam menjaga lingkungan merupakan sasaran utama. Untuk itu edukasi masyarakat perlu terus dilakukan secara intensif. Wilayah dusun Ciren, Triharjo, Pandah, Bantul, DIY merupakan salah satu yang memerlukan pendampingan dan edukasi tersebut. Metode yang digunakan adalah penyuluhan yang meliputi ceramah, diskusi, dan survei terkait pengetahuan tentang DBD, cara pencegahannya, identifikasi gejala, serta kesiap-siagaan dalam merespon gejala. Hasil survei menunjukkan tingkat pemahaman tentang penyakit DBD sebesar 90,4 $\%$, pemahaman tentang upaya pencegahan sebesar $78,6 \%$, penggunaan larvasida dan insektisida sebesar $35,7 \%$, pemahaman tentang gejala dan penanganannya sebesar 92,8\%. Dalam hal ini menandakan bahwa masyarakat memiliki tingkat pemahaman medium namun belum cukup memuaskan.
\end{abstract}

KATA KUNCI Demam berdarah; antisipasi, pencegahan, gejala.

ABSTRACT Indonesia is tropical country which holds contagious disease problem such as Dengue Hemorrhagic Fever (DHF). Aedes aegypti and Aedes albocpictus, the mosquito species play as dengue vector, can multiply rapidly in warm and humid tropical climate with high precipitation and rainfall. Incident rate of DHF in Indonesia fluctuates each year, indicating that the prevention has not been consistent. Prevention approach by changing community behavior for environmental health is the main objective. Therefore, a continuous and sustainable community education is necessary. Ciren village, Triharjo, Pandak, Bantul, DIY was one out of many communities area which needed assistance to improve knowledge regarding DHF. Assisting method performed were teaching, discussion, and survey of the related knowledge, including the basic knowledge of DHF, prevention method, identification of the symptom, and responsiveness. Results showed the comprehension of respondent regarding basic knowledge about DHF was $90.4 \%$, the comprehension of prevention was $78.6 \%$, the use of larvicide and insecticide was $35.7 \%$, comprehension of symptom and to quick respond was $92.8 \%$. It denotes that the surveyed community had medium but narrowly satisfying comprehension .

KEYWORDS Dengue fever; anticipation; prevention; symptoms. 


\section{Pendahuluan}

Demam Berdarah Dengue (DBD) merupakan penyakit yang ditimbulkan oleh infeksi virus dengue, dan ditularkan pada manusia dengan perantara gigitan nyamuk Aedes aegypti dan Aedes albocpictus. Faktor cuaca dan musim memiliki pengaruh dalam potensi penyebarannya karena merupakan faktor pendukung hidup dan populasi nyamuk. Iklim tropis seperti di Indonesia yang hangat dan lembab, musim hujan yang menyebabkan banyak genangan air merupakan dua faktor utama bagi perkembangan populasi nyamuk [1, 2, 3, 4], termasuk spesies Aedes aegypti dan Aedes albocpictus sebagai host virus dengue penyebab DBD. Selain faktor iklim dan curah hujan, jarak sarang nyamuk dengan area pemukiman penduduk juga mempengaruhi risiko penularan virus dengue dari vektor nyamuk ke manusia [5].

Catatan kejadian DBD yang diterbitkan oleh Kemenkes RI pada 6 tahun terakhir adalah: 101.000 pada tahun 2014, 129.000 kejadian pada tahun 2015, 204.000 kejadian pada tahun 2016, 68.000 kejadian pada tahun 2017 dengan 493 orang meninggal [6], 65.000 kejadian pada tahun 2018 dengan 469 orang meninggal [7], 137.761 kejadian pada tahun 2019 dengan 917 orang meninggal [8]. Dari angka jumlah penderita didominasi oleh usia anak 5-14 tahun mencapai $42 \%$ [8]. Dari data tersebut tampak bahwa pada tahun 2017-2018 angka kejadian menurun hingga 70\% dari tahun 2016. Namun, catatan pada tahun 2019 terjadi trend peningkatan angka kejadian. Kesulitan mengatasi kasus DBD di Indonesia disebabkan berbagai faktor, salah satunya bahwa tingkat kewaspadaan dan antisipasi yang dilakukan kurang konsisten [9, 10]. Hal ini menegaskan bahwa segenap masyarakat perlu memahami bahwa antisipasi dan kewaspadaan harus terus dilakukan secara reguler.

Standard teknik pencegahan DBD adalah dengan pengendalian vektor atau perantara nyamuk meliputi manajemen lingkungan, kendali secara kimia, perlindungan diri dan rumah, serta kendali secara biologis [11, 12, 13]. Manajemen lingkungan yang dimaksud meliputi mengurangi habitat larva nyamuk, membersihkan tempat penampungan air secara reguler, recycle barang bekas yang berpotensi menampung air, mengurangi kontak manusia dan vektor seperti penggunaan filter/jaring pada celah-celah rumah atau penggunaan kelambu $[11,12$, 13]. Kendali secara kimia meliputi penggunaan larvasida dan obat nyamuk (insektisida) dengan dosis yang aman $[11,12,13]$. Perlindungan diri dan rumah dapat dilakukan dengan menggunakan pakaian yang dapat meminimalkan ekspos kulit tubuh, serta penggunaan repellent [11]. Kendali secara biologis dapat diupayakan misal dengan memodulasi ekosistem sehingga terjadi kompetisi spesies atau memangsa larva atau nyamuk, contohnya dengan melepas ikan atau krustasea predator larva pada kolam atau genangan air $[11,12,13]$. Cara lain yang dianjurkan antara lain penggunaan ovitrap, jebakan nyamuk untuk kemudian dapat mengurangi jumlah vektor di lingkungan sekitar rumah [11].

Dusun Ciren berlokasi di Desa Triharjo, Kecamatan Pandak, Kabupaten Bantul, DIY [14] merupakan area pemukiman pedesaan dengan terdapat banyak kebun dan berdekatan dengan area persawahan padi. Secara demografis memiliki proporsi balita dan anak-anak yang relatif rentan terjangkit penyakit DBD karena kebiasaan aktifitas outdoor yang intens. Sejumlah upaya warga dalam mengantisipasi DBD sudah dilakukan namun masih ada beberapa warga yang mengalami infeksi DBD. Dalam hal ini, diperlukan penyegaran kembali (refresh) pengetahuan mengenai teknik-teknik antisipasi, pencegahan dan perhatian terhadap DBD bagi pamong warga beserta warga masyarakat dusun Ciren, Triharjo, Pandak, Bantul, DIY sehingga kemudian dapat melakukan upaya pencegahan secara lebih komprehensif di lingkungan dusun. 


\section{Metode}

Program dilakukan dengan metode penyuluhan, meliputi ceramah materi, diskusi tanya jawab, serta pendataan pemahaman peserta melalui kuesioner. Pelaksanaan program ini dilakukan dengan melibatkan pamong warga (kepala dusun, ketua RT) serta sejumlah warga masyarakat dusun Ciren, Triharjo, Pandak, Bantul, DIY pada bulan Februari 2020. Kegiatan yang dilakukan berupa penyuluhan kesehatan dan pelatihan dengan metode sebagai berikut:

a. Penyampaian materi

Materi disampaikan pada warga masyarakat beserta pamong warga secara komunikatif dan sedapat mungkin supaya dipahami dengan baik. Media yang digunakan adalah display power point melalui proyektor, serta brosur yang dibagikan pada peserta.

Materi yang disusun berdasar standard panduan WHO [11] dan Kemenkes $[12,13]$ meliputi dasar-dasar tentang penyakit DBD, metode-metode pencegahan, antisipasi, penandaan gejala, serta penanganan segera saat timbulnya gejala.

b. Diskusi tanya jawab

Diskusi dan tanya jawab dilakukan mengalir bersama ceramah materi. Setiap segmen materi disisipkan umpan bagi peserta/warga jika terdapat tanggapan atau pertanyaan. Setiap tanggapan dan pertanyaan dari peserta direspon secara sesuai.

c. Pendataan pemahaman dan respon warga melalui kuesioner (postest)

Kuesioner (postest) disusun untuk mendalami tingkat pemahaman dan respon warga setelah dilaksakan penyampaian materi dan diskusi. Kuesioner berisi 15 pertanyaan tertutup (pilihan ya dan tidak) terkait penyakit DBD, tindakan pencegahan, serta kewaspadaan terhadap gejala penyakit. Data hasil isian kuesioner (postest) kemudian diolah dengan analisa deskriptif berdasar kelompok variabel.

\section{Hasil dan Pembahasan}

Peserta kegiatan merupakan warga dusun Ciren, desa Triharjo, kecamatan Pandak, kabupaten Bantul, propinsi DIY, terdiri dari pamong warga yang meliputi kepala dusun (dukuh), ketua RT dan RW, serta warga masyarakat berusia dewasa. Suasana pasca kegiatan antara tim penyuluhan dan warga tersaji pada Gambar 1.

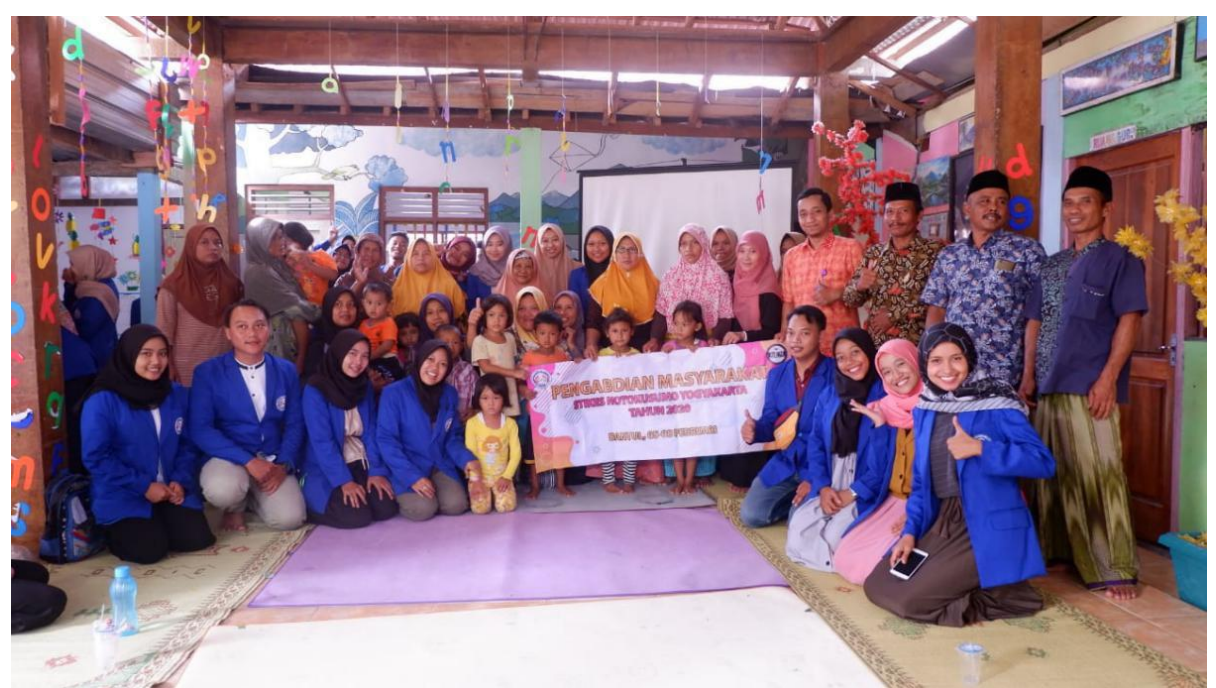

Gambar 1. Tim pelaksana pengabdian masyarakat bersama warga dusun Ciren pasca penyuluhan 
Distribusi jenjang pendidikan peserta tersaji pada Gambar 2A, yang terbagi hampir sama antara jenjang SD, SLTP, dan SLTA dalam rentang berkisar 30\%. Sementara jenjang pendidikan setara pendidikan tinggi sebesar 5\% dari seluruh peserta. Sedangkan dari sebaran usia peserta yang tersaji pada Gambar 2B, dapat dilihat profil usia didominasi oleh rentang usia 36-50 tahun. Dengan data sebaran peserta ini, dapat digunakan dalam melakukan penyesuaian metode komunikasi terkait penyuluhan yang dilakukan, yaitu dengan menggunakan bahasa lokal (bahasa Jawa) supaya materi dapat lebih dipahami oleh peserta terkait.

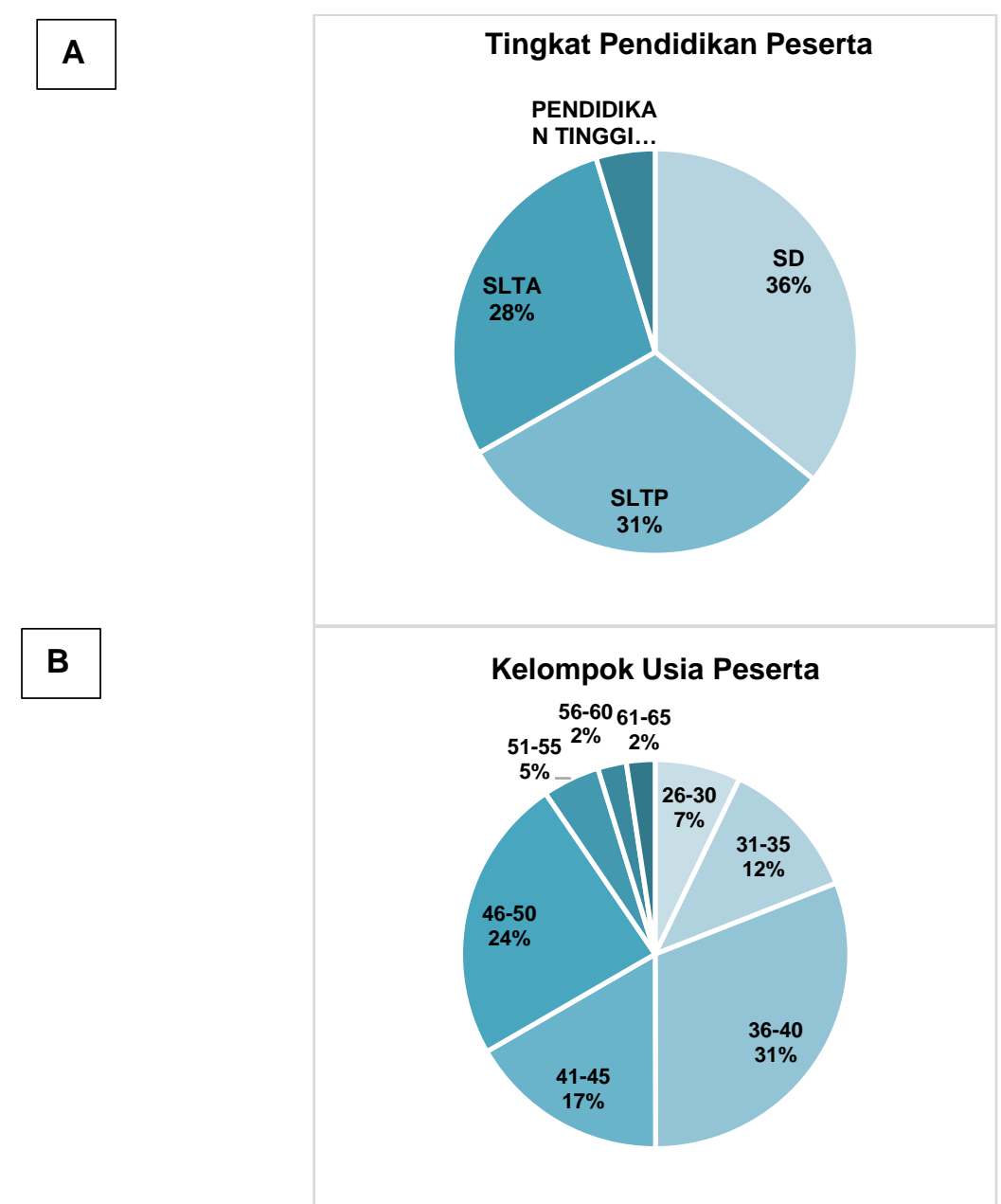

Gambar 2. Grafik Tingkat Pendidikan Peserta (A), dan Kelompok Usia Peserta (B)

Dari keseluruhan peserta, terdapat $17 \%$ warga yang anggota keluarganya pernah mengalami sakit DBD. Kemudian kriteria survei kuesioner lainnya dikelompokkan menjadi 4 grup, yaitu (1) pertanyaan yang terkait pengetahuan umum tentang DBD, (2) tindakan pencegahan DBD, (3) penggunaan larvasida dan insektisida (fogging), (4) serta kemampuan mengenali gejala dan respon terhadap gejala. Kuesioner diberikan satu kali sebagai postest setelah rangkaian materi penyuluhan dan diskusi diselesaikan. Hasil data disajikan pada Tabel 1.

Pertanyaan terkait pengetahuan umum tentang DBD meliputi jenis penyakitnya yang merupakan penyakit menular yang diperantarai oleh nyamuk, serta suasana lingkungan yang berpotensi menjadi sarang nyamuk. Dari keseluruhan responden, terdapat $90,4 \%$ yang menjawab sesuai dengan pengetahuan yang benar, sementara terdapat $9,6 \%$ yang menjawab tidak sesuai. Selanjutnya, terkait survei tindakan pencegahan DBD meliputi kebiasaan kerja bakti pembersihan lingkungan, menutup penampungan air, mengelola barang bekas yang dapat menampung air, rutin menguras penampungan air, penggunaan filter/kasa pada ventilasi/jendela, 
penggunaan pelindung anti-nyamuk. Perolehan data menunjukkan bahwa 78,6\% responden melakukan tindakan pencegahan yang sesuai, dan masih terdapat $21,4 \%$ yang belum melakukan tindak pencegahan dengan tepat.

Pada kelompok survei ke-3 terkait penggunaan larvasida dan insektisida, hanya sebanyak 35,7\% masyarakat yang menggunakan metode kimia ini. Terkait kewaspadaan dalam mengenali gejala dan penanganan gejala, 92,8\% responden mengaku dapat melakukan sesuai dengan anjuran, namun masih terdapat 7,2\% yang masih belum dapat mengenali ataupun cepat tanggap terhadap gejala DBD.

Tabel 1. Distribusi Tingkat Kesesuaian Pengetahuan Responden tentang DBD

\begin{tabular}{lcc}
\hline \multirow{2}{*}{ Kategori Pengetahuan/Tindakan } & \multicolumn{2}{c}{ Rata-Rata Respon Peserta [n (\%)] } \\
\cline { 2 - 3 } & Sesuai & Tidak sesuai \\
\hline Pengetahuan umum tentang DBD & $38(90,4)$ & $4(9,6)$ \\
\hline Tindakan pencegahan DBD & $33(78,6)$ & $9(21,4)$ \\
\hline $\begin{array}{l}\text { Penggunaan larvasida dan insektisida } \\
\text { fogging) }\end{array}$ & $15(35,7)$ & $27(64,3)$ \\
\hline Mengenali dan tanggap gejala & $39(92,8)$ & $3(7,2)$ \\
\hline
\end{tabular}

Penyuluhan serupa dilakukan di kelurahan Sukagalih Bandung pada Desember 2018 dan dinilai dapat meningkatkan pemahaman masyarakat menjadi 85,6\% [15]. Penelitian serupa juga dilakukan oleh Puslitbang Upaya Kesehatan Masyarakat, Badan Penelitian dan Pengembangan Masyarakat, Kementrian Kesehatan RI pada tahun 2016 di wilayah Jawa Barat dan Kalimantan Barat, yaitu dengan pengambilan data responden melalui satu kali kuesioner tanpa intervensi penyuluhan. Dengan perolehan data $77 \%$ responden memahami DBD sebagai penyakit menular, $81,5 \%$ responden mengetahui cara penularan DBD, dan $63,7 \%$ responden melakukan tindak pencegahan, kriteria tersebut dianggap masih kurang memuaskan [16].

Perbandingan hasil yang diperoleh dari satu kali kuesioner dari Puslitbang Upaya Kesehatan Masyarakat [16] dan hasil pengukuran pemahaman warga Dusun Ciren, berturut-turut adalah sebagai berikut: pada kriteria pengetahuan umum responden terkait DBD adalah $81,25 \%$ dan $90,4 \%$; pada kriteria pemahaman responden terkait tindakan pencegahan adalah $63,7 \%$ dan $78,6 \%$. Dengan melihat trend data yang diperoleh dapat dikatakan bahwa tingkat pemahaman warga dusun Ciren lebih baik daripada hasil survey Puslitbang Upaya Kesehatan Masyarakat. Untuk itu pengetahuan warga dusun Ciren dikategorikan pada level medium/menengah, namun belum cukup memuaskan untuk memaksimalkan kewaspadaan terhadap risiko DBD. Masih terdapat 21,4\% masyarakat yang tidak memahami dengan baik jenis tindakan pencegahan yang perlu dilakukan, serta masih terdapat $7,2 \%$ masyarakat yang belum mengenali gejala dan tidak merasa perlu bergegas melakukan penanganan terhadap gejala.

\section{Kesimpulan}

Setelah dilakukan penyuluhan, dapat ditarik kesimpulan bahwa kelompok warga masyarakat dusun Ciren, Triharjo, Pandak, Bantul, DIY memiliki pemahaman pada tingkat medium/menengah, yang mana tidak buruk namun belum sangat memuaskan. Kegiatan penyuluhan belum efektif untuk mencapai pemahaman mendekati 100\%. Namun demikian diharapkan bahwa angka kejadian DBD di dusun Ciren, Triharjo, Pandak, Bantul, DIY akan berkurang. Edukasi, pendampingan, dan pemberdayaan masyarakat terkait kebiasaan hidup sehat serta pencegahan penyakit perlu terus dilakukan secara intensif dalam rangka mencapai efisiensi kesehatan masyarakat. 


\section{Ucapan terima kasih}

Terima kasih disampaikan kepada Ketua, Wakil Ketua III, Kepala Lembaga Penelitian dan Pengabdian Kepada Masyarakat, dan Badan Eksekutif Mahasiswa Sekolah Tinggi Ilmu Kesehatan Notokusumo Yogyakarta, serta Kepala Dusun beserta warga dusun Ciren, Triharjo, Pandak, Bantul DIY atas dukungan dan kerjasama bagi terlaksananya kegiatan pengabdian kepada masyarakat ini.

\section{Daftar pustaka}

[1] Suwito, Hadi, U. K., \& Sigit, S. H. (2010). Hubungan Iklim, Kepadatan Nyamuk Anopheles dan Kejadian Penyakit Malaria. Jurnal Entomol Indonesia, 7(1), 42-53.

[2] K, Winahju, \& Mukarromah. (2012). K, D. R., Winahju, W. S., \& Mukarromah, A. (2012). Pemodelan Pengaruh Iklim Terhadap Angka Kejadian Demam Berdarah Dengue di Surabaya. Jurnal Sains Dan Seni ITS, 1(1), D-69-D-74.

[3] Sunaryo \& Pramestuti. (2014). Sunaryo, \& Pramestuti, N. (2014). Surveilans Aedes aegypti di Daerah Endemis Demam Berdarah Dengue Aedes aegypti Surveillance in Endemic Area of Dengue Haemorrhagic. Kesmas National Public Health Journal, 8(8), 423-429.

[4] Halim, Farmadi, \& Budiman. (2015). Halim, M., Farmadi, A., \& Budiman, H. I. (2015). Melihat Pengaruh Cuaca Terhadap Penyakit Demam Berdarah Di Banjarbaru menggunakan Fuzzy C-Means. Jurnal Ilmiah KLIK, 2(2), 36- 49.

[5] Ridha, M. R., Juhairiyah, \& Fakhrizal, D. (2018). Pengaruh Iklim Terhadap Peluang Umur Nyamuk Mansonia spp di Daerah Endemis Filariasis di Kabupaten Kapuas. Jurnal Kesehatan Lingkungan Indonesia, 17(2), 74-79.

[6] Kemenkes RI. (2018) "Situasi Penyakit Demam Berdarah di Indonesia Tahun 2017," Info Datin, Pusat Data dan Informasi Kementrian Kesehatan RI.

[7] M. Zulfikar, \& Z. Meirina. (2019) "Kemenkes Catat 110.921 Kasus DBD hingga Oktober 2019," Antaranews, 5 November 2019.

[8] M. Zulfikar, \& D. Purnamawati, (2020). "Kemenkes Catat 94 Orang Meninggal Akibat DBD hingga Maret 2020," Antaranews, 5 Maret 2020.

[9] T. Respati, A. Raksanegara, H. Djuhaeni, A. Sofyan, D. Agustian, L. Faridah, H. Sukandar. (2017). "Berbagai Faktor yang Mempengaruhi Kejadian Demam Berdarah Dengue di Kota Bandung". Aspirator, vol. 9 (2), pp 91-96.

[10] S.A. Nursastri. (2020). "Sudah 50 Tahun, Mengapa DBD di Indonesia Sulit Diatasi?", Kompas, 12 Februari 2020.

[11] WHO, (2009) "Dengue Guidelines for Diagnosis, Treatment, Prevention, and Control," WHO Press, pp. 3-17, 59-86.

[12] Kementrian Kesehatan Republik Indonesia. (2011). "Modul Pengendalian Demam Berdarah Dengue", Direktorat Jenderal Pengendalian Penyakit dan Penyehatan Lingkungan.

[13] Kementrian Kesehatan Republik Indonesia. (2017). "Pedoman Pencegahan dan Pengendalian Demam Berdarah Dengue di Indonesia", Direktorat Jenderal Pencegahan dan Pengendalian Penyakit.

[14] Peta Dusun Ciren, Triharjo, Pandak, Bantul, DIY, https://goo.gl/maps/S4S1vpPJQFkH7BV49

[15] Ratnadewi, M. Christine, R.T. Manurung, T.L. Wargasetia, Dani, (2019). "Pelatihan Pencegahan dan Penanggulangan Demam Berdarah Dengue," Celebes Adimas, vol 1 (1), pp. 36-44.

[16] H.S.P. Manalu, dan A. Munif, (2016). "Pengetahuan dan Perilaku Masyarakat dalam Pencegahan Demam Berdarah Dengue di Provinsi Jawa Barat dan Kalimantan Barat," Aspirator, vol. 8 (2), pp. 69-76. 